\title{
CONGENITAL DIAPHRAGMATIC HERNIAS
}

\author{
KONJENITAL DIYAFRAM HERNILERI
}

\author{
Mehmet Oğuzhan Özyurtkan, Murat Kılıç \\ Department of Thoracic Surgery, Faculty of Medicine, Fırat University, Elazığ, Turkey \\ e-mail: moozyurtkan@hotmail.com \\ doi:10.5152/tcb.2012.38
}

\begin{abstract}
Congenital diaphragmatic hernia $(\mathrm{CDH})$ is a birth anomaly where there is a defect in the diaphragm. Bochdalek hernia accounts for more than $95 \%$ of $\mathrm{CDH}$, followed by Morgagni hernia, and other lesser types. The pathology of CDH comprises three elements: the diaphragmatic hernia, pulmonary hypoplasia, and herniation of the abdominal organs into the thorax. Associated syndromic or nonsyndromic anomalies occur commonly in $\mathrm{CDH}$. Prenatal diagnosis might be possible in the majority of the cases by using ultrasound. Several nonsurgical attempts have gained importance in the presurgical stabilization of patients with $\mathrm{CDH}$, mostly with the Bochdalek type, since it became clear that the mortality depends largely on the degree of the pulmonary hypoplasia and pulmonary hypertension. In the surgical treatment of $\mathrm{CDH}$, minimally invasive methods (mostly laparascopic surgery) have gained popularity compared with the traditional approaches through thoracotomy or laparatomy.
\end{abstract}

Key words: Diaphragmatic hernia, Pulmonary hypoplasia, Pulmonary hypertension, Surgery

\section{DEFINITION AND CLASSIFICATION}

Congenital diaphragmatic hernia $(\mathrm{CDH})$ is a birth anomaly where there is a defect in the diaphragm. Bochdalek hernia, which involves a posterolateral defect with herniation of the abdominal organs into the thoracic cavity, and a varying degree of lung hypoplasia, accounts for more than $95 \%$ of $\mathrm{CDH}$. Non posterolateral hernias are classified into three groups: (a) retrosternal or parasternal (Morgagni-Larrey); (b) other anterior hernias that extend into the anterior portion of the central tendon and are associated with other anomalies; and (c) central hernias, where the defect primarily involves the non-muscular central tendinous part of the diaphragm (1).

\section{Özet}

Konjenital diyafram hernisi $(\mathrm{KDH})$, diyaframda bir defektin bulunduğu doğumsal bir anomalidir. KDH'nin \%95'inden fazlasını Bochdalek hernisi, geri kalanlarını Morgagni hernisi ve diğer nadir tipler oluşturur. KDH'nin patolojisinde diyafram hernisi, akciğer hipoplazisi ve batın organlarının toraks içi yer değiştirmesi olmak üzere üç öğe bulunur. KDH'ye sıklıkla, bir sendroma ait olsun veya olmasın, başka bir anomali eşlik eder. Hastalığın doğum öncesi tanısı özellikle ultrason incelemesiyle mümkündür. Mortalitenin büyük oranda eşlik eden akciğer hipoplazisi ve pulmoner hipertansiyona bağlı olduğunun anlaşılması, özellikle Bochdalek hernisinde, operasyon öncesi çeşitli cerrahi dışı yöntemlerin kullanımını öne çıkarmıştır. KDH'nin cerrahi tedavisinde torakotomi veya laparatomi şeklindeki geleneksel yaklaşımların yanı sıra minimal invaziv yaklaşımlar (özellikle laparaskopik cerrahi) popülarite kazanmaktadır.

Anahtar kelimeler: Diyafram hernisi, Akciğer hipoplazisi, Pulmoner hipertansiyon, Cerrahi

\section{HISTORY (2-4)}

In 1679, Lazarus Riverius recorded the first reported case of $\mathrm{CDH}$ following a postmortem examination of a 24-year-old male. In 1701, Holt reported the first case of CDH in a child. In 1827, Cooper described the symptoms, pathology and classification of $\mathrm{CDH}$. In 1847, Bowditch presented the first collected series of patients with $\mathrm{CDH}$ in the Boston Society for Medical Observation. Then, in 1848, Bochdalek described the $\mathrm{CDH}$ that occurs posterolaterally, which now bears his name.

The first attempt at surgical repair of $\mathrm{CDH}$ was made by Nauman in 1888; the 19-year-old patient presented 
with acute respiratory distress and acute abdomen, and a laparotomy was performed. In 1889, O'Dwyer carried out the first repair of $\mathrm{CDH}$ in an infant. The first successful repair was performed by Heidenhain in 1905 in a 9 year old patient when he reduced the hernia and closed the diaphragmatic defect through a midline laparotomy incision. Nearly 20 years later, Hedbolm reported a $58 \%$ mortality rate for patients undergoing surgical intervention for CDH. In 1940, Ladd and Gross based their diagnosis of $\mathrm{CDH}$ on the history, physical examination findings, and findings on chest radiography with or without a barium meal. They advocated early surgical intervention within the first 2 days. Gross also described a two-stage closure of the abdominal wall in difficult cases; closure of skin and subcutaneous fascia at the initial surgery and closure of the abdominal wall 5 to 6 days later. In 1950, Koop and Johnson suggested the transthoracic approach as a means of closing the defect under more direct vision.

In the 1960s, however, Areechon and Reid observed that the high mortality rate of $\mathrm{CDH}$ was related to the degree of pulmonary hypoplasia at birth. In 1976, ECMO (Extracorporeal Membrane Oxygenation) was first used successfully in the treatment of persistent pulmonary hypertension. Subsequently, this procedure started to be used in the treatment of $\mathrm{CDH}$. Over the past 20 years, pulmonary hypertension and pulmonary hypoplasia have been recognized as the two cornerstones of the pathophysiology of $\mathrm{CDH}$. In recent years, evidence suggests that cardiac maldevelopment may further complicate the pathophysiology of $\mathrm{CDH}$.

\section{ETIOLOGY AND PATHOPHYSIOLOGY}

The pathology of CDH comprises three elements: the diaphragmatic hernia, pulmonary hypoplasia, and herniation of the abdominal organs into the thorax. The mechanisms underlying the etiology of $\mathrm{CDH}$ remain obscure, but there exist some theories. First, a persistent theory states that the diaphragmatic malformation is a secondary defect caused by the maldevelopment of the adjacent lung tissue. Second, a perturbation of the normal innervation of the diaphragm by the phrenic nerve may subsequently arrest adequate diaphragmatic muscle development. A third explanation, which is the most commonly cited and the traditionally accepted mechanism, states that there is an abnormality with the closure of the pleuroperitoneal canal. Fourthly, it has been suggested that the developing muscle fibers within the region of herniation fail to form or are weak and prone to rupture in the presence of underlying forces produced by the expanding abdominal contents $(5,6)$. In addition, it is believed that the defect is related to one or several genes that guide normal diaphragm development. Teratogenic factors, including vitamin A deficiency, anti-epileptic medication, and thalidomide have also been implicated (7-9).

The pathophysiology is thought to result from a dual-hit hypothesis, with injury to both the ipsilateral and contralateral lung. First, early in gestation (5-16 weeks), there is loss of space for the developing lung causing decreased bronchial branching and resulting in fewer alveoli. Second, with further compression of the developing lung, a reduction in airway size, decreased alveoli, increased interstitial tissue and diminished alveolar air space and gas exchange surface area result. At the same time, vascular changes occur. These include a reduced number of vessels and abnormal extension of the muscular layer into the small intra-acinary arterioles. In very severe cases, left ventricular hypoplasia is observed. Pulmonary capillary blood flow is decreased because of the small cross-sectional area of the pulmonary vascular bed, and flow may be further decreased by abnormal pulmonary vasoconstriction. These alterations become evident postnatally as pulmonary hyoplasia and pulmonary hypertension. The severity of these changes has the most important effect on survival $(10,11)$.

\section{Epidemiology and Associated diseases/anomalies}

$\mathrm{CDH}$ occurs with an incidence of $1 / 2500$, and, if stillborn pregnancies are included, 1/5000 (12). About $85-90 \%$ of $\mathrm{CDH}$ is on the left side, $10-15 \%$ on the right side and $2 \%$ bilateral. In nearly $60 \%$ of the cases, the disorder is isolated, occurring in the absence of additional congenital malformations (13). Nonsyndromic associated anomalies ranging from $16 \%$ to $53 \%$ of cases, include cardiovascular (14-27\%), urogenital tract $(5-18 \%)$, musculoskeletal $(7-16 \%)$, central nervous system (10-13\%), gastrointestinal (6\%), craniofacial $(5 \%)$ and pulmonary $(2 \%)$ defects. When multiple anomalies exist, the diaphragmatic defect is often large andĞor bilateral (14). Associated anomalies occur commonly in $\mathrm{CDH}$, in as many as $40 \%$ of cases. In $\mathrm{CDH}$ cases of stillbirth or intrauterine demise, this figure rises to $95 \%$ (15). Numerical chromosomal abnormalities (trisomy 18 or tetrasomy) or complex structural chromosomal abnormalities (e.g. unbalanced translocations in chromosomes 11 and 22, deletions $12 q, 4 p, 8 p$ ) appear in $3-40 \%$ of $\mathrm{CDH}(1)$. Cytogenetic and molecular cytogenetic studies demonstrate an association between $\mathrm{CDH}$ and chromosome 1q41q42 deletions (16). Although most isolated 
hernias are sporadic, there are reports in siblings, twins and in two generations (8). Genetic syndromes associated with $\mathrm{CDH}$ include Fryns, Brachman de Lange, CHARGE, Goldenhar, Smith-Lemli-Opitz, SimpsonGolabi-Behmel, Fraser, Beckwich-Weidemann, Denys Drash, Marfan, craniofrontonasal syndrome, multiple pterygium, Noonan and spondylocostal dysostosis $(9,11)$. Cardiac anomalies are also described in $10 \%$ of patients with $\mathrm{CDH}$. Both serious heart defects and genetic abnormalities have an adverse effect on survival. Therefore, complete diagnostic work-up with fetal echocardiography and prenatal karyotype via amniocentesis is essential (17).

\section{DIAGNOSIS}

\section{Prenatal diagnosis}

Ultrasound is the imaging modality of choice in pregnancy. It lacks ionizing radiation, can be portable, and offers real-time imaging and color Doppler for vascular analysis without maternal discomfort. Restrictions of the technique include limited softtissue contrast, small field of view and technical deficiencies in the presence of oligohydramnios, fetal position, ossified structures obscuring details of an area and maternal obesity. Ultrasound screening results in an overall detection rate of $59 \%$ of $\mathrm{CDH}$ cases, usually after 24 weeks of gestation, with improved detection at a later gestational age and in the presence of associated anomalies (18). Prenatal diagnosis is particularly difficult before 24 weeks of gestation (22-52\% of the cases), and even after 24 weeks of gestation, the prenatal diagnosis is a challenge, with more than $25 \%$ of cases missed and $11 \%$ diagnosed postnatally (19). The diagnosis of $\mathrm{CDH}$ is usually suspected when the stomach is not observed in the normal intra-abdominal location. Diagnosis is identified by detecting direct signs of an intrathoracic mass containing the liver, bowel or stomach or by indirect evidence such as abnormal cardiac axis, mediastinal shift, scaphoid abdomen or polyhydramnios (20).

Fetal MRI has proved useful as an adjunct to prenatal sonography. Advantages of this technique include large field of view and excellent soft-tissue discrimination. It is not limited by fetal position, shadowing from ossified structures or oligohydramnios. Fetal MRI typically is not performed in the first trimester because of concern regarding teratogenesis. Fetal MRI in the evaluation of $\mathrm{CDH}$ has proved helpful for confirming diagnosis, providing detailed anatomy, and evaluating or confirming associated anomalies (21).

\section{Postnatal diagnosis}

Up to $50 \%$ of babies with a $\mathrm{CDH}$ remain undiagnosed until birth. The classical presentation in these babies is of a term infant with acute respiratory distress shortly after, or within, $12 \mathrm{~h}$ of birth. An X-ray reveals the characteristic combination of bowel loops within the chest, lung hypoplasia, and mediastinal shift away from the side of the hernia. An orogastric tube placed into the stomach to decompress the intestines may appear in the chest, and a paucity of gas exists in the abdomen (11).

Some patients are asymptomatic and the hernia goes undetected for months or years. These patients have normal lungs and the transition to extrauterine life is unremarkable. The radiological studies in the evaluation of nonspecific symptoms or taken for another reasons may demonstrate the presence of a $\mathrm{CDH}$. The imaging findings may be very confusing in such patients, since they mimic almost any acute chest problem, such as pneumonia with cavitation, pleural effusion, massive pneumothorax and pneumatoceles. In terms of the abdominal plain film findings in children with delayed $\mathrm{CDH}$, the visualisation of the gastric bubble, which is almost always seen under the diaphragm on the left side, is very helpful. With left-sided $\mathrm{CDH}$, the bubble is not usually visible in the abdomen. It may be in an abnormal location in the abdomen or the chest. As a result, this finding becomes very useful in a rapid, early diagnosis of late-presenting $\mathrm{CDH}(22)$.

\section{PROGNOSTIC FACTORS}

\section{Anatomical factors}

- Prenatal diagnosis: This itself is not a poor prognostic factor, but fetuses with an antenatally diagnosed $\mathrm{CDH}$ are more likely to have other anomalies, which might have a significant adverse effect on the prognosis $(1,19)$.

- Polyhydramnios is a poor prognostic indicator $(1,11)$.

- Large sized CDHs have a poor prognosis (1).

- Stomach herniation: The prognosis is not good if the stomach is in the hemithorax (11).

- Laterality: Historically, the side of the hernia was thought to predict outcome, with right sided hernias carrying a worse prognosis than left. There are also some reports demonstrating that bilateral CDH carries a poor prognosis (11).

- Liver herniation: The position of the fetal liver alone is the best prognostic indicator for isolated left-sided $\mathrm{CDH}$. This demonstrates a poor prognosis $(1,11)$.

- Measurement of fetal lung to head ratio (LHR) has gained popularity in recent years as a method of 
determining prognosis. Two-dimensional US is used to calculate the ratio of the area of the contralateral fetal lung at the level of the four chamber view of the heart to the fetal head circumference at the level of the lateral ventricles. A LHR value less than 1 has a mortality rate of nearly $100 \%$ (23).

- Cannie et al. (24) reported the use of magnetic resonance imaging (MRI) as a new method for predicting outcome in antenatally diagnosed $\mathrm{CDH}$. They correlated total fetal lung volume with total fetal body volume to generate a lung volume observedexpected ratio. A ratio below $35 \%$ predicted a poor prognosis.

- Birth weight less than $2.7 \mathrm{~kg}(1)$.

\section{Physiological factors}

- Postnatal mortality is the result of respiratory failure due to a combination of pulmonary hypoplasia and pulmonary hypertension. The degree of pulmonary hypoplasia is variable, with some infants succumbing very soon after birth, while others have apparently normal lungs. The disturbed $\mathrm{PaCO}_{2}, \mathrm{PaO}_{2}$ and $\mathrm{pH}$ values are poor prognostic indicators (11).

- Postductal partial pressure of oxygen less than 100 $\mathrm{mmHg}$, and an alveolar/arterial oxygen gradient of more than 500 carry high mortality rate (11).

- McGoon index calculated using the formula [MGI: (RPA diameter+LPA diameter)/DA diameter] and pulmonary artery index calculated using the Formula [PAl: (RPA area+LPA area)/BSA] are two indices demonstrating the survival of patients with CDH (RPA: right pulmonary artery, LPA: left pulmonary artery, DA: descending aorta, BSA: body surface area) (25).ckm

- Day 1 best oxygenation index (BOI, d1) of >82 (calculated from the best blood gas on the first day of life as [fractional inspired $\mathrm{O}_{2}(\%) \times$ mean airway pressure $\left.\left.\left(\mathrm{cmH}_{2} \mathrm{O}\right)\right] \mathrm{ĞPaO}_{2}(\mathrm{kPa})\right)(1)$.

\section{PRENATAL INTERVENTIONS}

\section{Open anatomical repair}

Prenatal correction of $\mathrm{CDH}$ was first attempted in 1986. Because of the risks inherent to the mother during fetal surgery, only the most severe cases (those with liver herniation) were initially offered intervention. Reduction of the liver back into the abdomen caused obstruction of the umbilical venous blood flow, leading to bradycardia and fetal demise. This obstruction was not a problem in fetuses with liverdown hernias. The first successful case of prenatal correction in a human fetus was reported in 1990 . The repair was technically feasible using a two-step technique involving a thoracotomy and a subcostal incision to reduce the viscera. Meanwhile, the survival in these infants was $75 \%$ as opposed to $86 \%$ in a group receiving traditional postnatal therapy. In addition, ECMO requirement, ventilator duration and hospital length of stay were similar between the two groups. Because prenatal intervention in this group did not improve mortality rates or morbidity, fetuses without liver herniation were excluded from future prenatal intervention (26).

\section{Physiological intervention by fetal tracheal occlusion (FETO)}

PLUG strategy ('Plug the Lung Until it Grows') is the manipulation of lung growth by tracheal occlusion to induce pulmonary hyperplasia and stimulate increased pulmonary vasculature via sequestration of lung fluid that enhances cell division. However, pathological studies of lung tissue from human fetuses with (intrauterine) corrected $\mathrm{CDH}$ by open prenatal tracheal occlusion showed increased lung growth, but no improvement in parenchymal structure or muscularization of pulmonary arteries. Subsequent technical refinement involved the introduction of an intratracheal balloon through the irrigating fetoscope, allowing deflation without additional surgery. However, this method has some restrictions such as preterm labour induction, and no advantage in neonatal survival or in rates of complications compared with optimal postnatal care (27).

The FETO Task Group proposed an algorithm for in utero intervention in antenatally diagnosed severe isolated $\mathrm{CDH}$ ( $<25$ weeks gestation): LHR $<1$ with liver herniated into the thoracic space benefits from 'FETO'between 26 and 28 weeks, while 'good'or 'intermediate'cases are deferred for postnatal therapy. The advantage of this approach has yet to be proven because survival is compared with that of contemporary controls rather than within a randomized study $(28,29)$.

\section{POSTNATAL INTERVENTIONS}

Until the 1980s, CDH was considered as a surgical emergency. This was based on the assumption that herniating abdominal viscera were the underlying pathologic feature of the disease, causing respiratory and hemodynamic compromise through compression of the lungs and mediastinum (30). This thinking was challenged by clinical reports of worsening respiratory compliance and pulmonary hypertension following surgical repair. Multiple factors can con- 
tribute to postoperative deterioration. These include pulmonary vasospasm secondary to stress, increased intra-abdominal pressure associated with reduction of herniating organs and abnormal respiratory mechanics. Justification for delayed surgery has come from single-institution retrospective reviews demonstrating increased survival compared to historical controls (31). Despite a lack of conclusive prospective data, early stabilization followed by delayed surgery has been widely adopted, based on the cumulative experience of high volume tertiary centers $(28,32)$.

According to the CDH EURO Consortium consensus published in 2010, the most important items in the postnatal management of patient with $\mathrm{CDH}$ are summarized as follows (33)

\begin{tabular}{|ll|}
\hline Treatment in the & No bag masking \\
delivery room & Immediate intubation \\
& Peak pressure $<25 \mathrm{cmH} 2 \mathrm{O}$ \\
& Nasogastric tube \\
Treatment in the & Adapt ventilation to obtain \\
intensive care unit & preductal saturation between \\
& 85-95\% \\
& pH $>7.2$, lactate 3-5 mmol/L \\
& Conventional ventilation or \\
& high-frequency oscillation \\
& Blood pressure targeting \\
& reference value for \\
& getastional age \\
Inotropic support & Echocardiography \\
Nitrous oxide inhalation \\
Treatment of pulmonary \\
hypertension & Phosphodiesterase inhibitors, \\
& endothelin antagonists, tyrosine \\
kinase inhibitors \\
Start if the patient can achieve \\
a preductal saturation $>85 \%$ \\
Inability to maintain preductal \\
saturation $>85 \%$ \\
Respiratory acidosis \\
Inadequate oxygen delivery \\
(lactate $>5$ mmol/L) \\
Therapy-resistant hypertension \\
FiO2 <0.5 \\
Mean blood pressure normal for \\
gestational age \\
Urine output $>2 \mathrm{~mL}$ kg-1 $\mathrm{h}^{-1}$ \\
No signs of persistent \\
pulmonary hypertension \\
\end{tabular}

Traditionally, $\mathrm{CDH}$ has been repaired through a subcostal incision on the side of the hernia. The objectives of the surgery are to reduce the hernial contents back into the abdomen, excise any hernia sac, and close the diaphragmatic defect. The method of closure depends on the size of the defect. Small defects are repaired primarily using non-absorbable sutures. This will allow the repair to grow with the patient. If there is a deficient or absent rim of diaphragm, sutures have to be anchored to the ribcage or the abdominal wall. It is important to avoid excessive tension in the repair to reduce the chances of a recurrence and achieve normal movement of the diaphragm (32).

Larger defects require the use of a patch. Various types of prosthetic materials and tissues have been used for this purpose (32). In a recent study, it was shown that the approach using split abdominal wall muscle flap for closure of a larger $\mathrm{CDH}$ was associated with fewer recurrences than patch repair (34). Another study demonstrated that patch repair correlates with higher long-term morbidity. Poorer auxological outcome and increased rate of gastroesophageal reflux (GER) were observed at follow-ups, especially in the first 6 months. Conversely, patch repair does not affect chest wall deformities in the first 2 years of life, but increases as time goes by (35).

Postsurgical complications include infection, erosion of patch into adjacent structures, chest wall deformity, restrictive lung disease and recurrence of the hernia. Recurrence is seen in up to $7 \%$ of children who have undergone a primary repair, occurring most commonly in the first year of life. Since prosthetic material does not grow with the patient, this form of repair has a high recurrence rate over time (up to $40 \%$ ) (36). Since the use of a patch again in the recurrence management has a higher recurrence rate and may lead to progressive chest wall deformity, autologous tissues such as latissimus dorsi and rectus abdominis muscle flaps, or free fascia lata repair are advised $(37,38)$.

Routine use of tube thoracostomy after surgery has been abandoned to avoid risk of infection and wide swings in intrathoracic pressure. Pleural fluid accumulating after surgery will be absorbed as the lung expands. Large effusions impairing respiration are drained via needle thoracocentesis. Closure of abdominal incision following repair of a large $\mathrm{CDH}$ can be challenging. Options include closure of skin alone, use of an inlay mesh sewn to the fascial edge and creation of a silo (32).

As minimally invasive surgery, thoracoscopy can be used in the correction of $\mathrm{CDH}$. The insufflation of the hemithorax with low pressure $\mathrm{CO}_{2}$ can facilitate thoracoscopic reduction of abdominal viscera, but this may exacerbate intraoperative respiratory acidosis. Infants with smaller hernias and on minimal ventilator settings are most suitable for thoracoscopy (32). Compared to 
open surgery, thoracoscopic surgery is associated with a higher rate of in-hospital recurrence. Recurrences can also be repaired using thoracoscopy (39).

\section{PROGNOSIS AND LONG-TERM SEQUELAE}

Survival rates for babies with $\mathrm{CDH}$ vary considerably from 50 to $80 \%$. There are a number of explanations for the variation in survival. a) Patient population, b) True differences in pathology severity, e.g. $\mathrm{CDH}$ associated with another lethal malformation, c) Other $\mathrm{CDH}$-specific factors, e.g. bilateral herniae, and d) Postnatal management (11).

A large number of babies with $\mathrm{CDH}$ survive with apparently normal lung function, although up to $25 \%$ will have some $\mathrm{CDH}$-related symptoms in later life. GER is a common complication of $\mathrm{CDH}$ contributing to growth retardation. GER is more common among patients requiring patch repair. Prophylactic fundoplication during patch repair has been associated with better survival without disordered growth. Therefore prophylactic fundoplication is an option in stable patients undergoing diaphragmatic repair, but further research is necessary before this can be widely adopted $(32,40)$.

Respiratory symptoms are related to primary lung hypoplasia, the sequelae of neonatal ventilation, and the effects of GER. Some children develop chronic lung disease, similar to that seen in premature infants, and require prolonged oxygen therapy. Some others are found to have reduced inspiratory muscle strength and a degree of small airway obstruction. Lastly, a small subset of patients have residual chronic pulmonary hypertension requiring longterm pulmonary vasodilator therapy (11).

Neurodevelopmental dysfunction has been recognized as the most common and potentially most disabling outcome of $\mathrm{CDH}$ and its treatment. Illness severity and the degree of pathophysiological disruption correlate with the severity of neurological delays. $\mathrm{CDH}$ might be associated with a high prevalence of structural brain abnormalities (41). Neurodevelopmental problems are more common in non-ECMO-treated $\mathrm{CDH}$ survivors (42). Other long-term problems in $\mathrm{CDH}$ patients include spine and chest wall deformities including pectus excavatum and scoliosis (11).

\section{LESS COMMON DIAPHRAGMATIC HERNIAS IN CHILDREN}

\section{Foramen of Morgagni Hernia}

On each side of the sternum there is a potential space known as the foramen of Morgagni, or the space of Larrey, through which the internal mammary artery passes to become the superior epigastric artery. This triangular space lies between the muscular fibers originating from the xiphisternum and the costal margin, which insert on the central tendon of the diaphragm (43). Giovanni Battista Morgagni first described the anterior congenital diaphragmatic hernia in 1769. The hernia defect is formed due to failure of fusion of sternal and costal parts of the diaphragm. It is defined as Larrey hernia when located on the left or as Morgagni hernia (MH) when located on the right of the sternocostal hiatus. If the opening is wide enough to include both hiatus, the defect is called Morgagni-Larrey hernia (44). $\mathrm{MH}$ account for 1-6\% of all surgically treated diaphragmatic hernias. The majority $(90 \%)$ occurs on the right side because of the presence of the heart and pericardial attachment to the left side. The left side is affected in $8 \%$ of the patients, and the hernia is bilateral in $2 \%$. A hernia sac is found in $95 \%$ of the cases. The omentum and/or the transverse colon are the most frequent contents found within the hernia sac (45).

In the pediatric age group, the presentation of $\mathrm{MH}$ is variable. A small $\mathrm{MH}$ is usually unrecognized, asymptomatic in infants and young children, and is discovered accidentally. Larger ones, often because of the presence of an abdominal viscus in the hernia, may produce respiratory symptoms. The dramatic clinical picture may be similar to that of a Bochdalek's hernia (43). Although some evidence has been found for the Bochdalek hernia with genetic mutations, it has not been reported for $\mathrm{MH}$ (46). Another interesting feature of $\mathrm{MH}$ is the high incidence of associated anomalies, such as Down's, Turner's, or Noonan's syndrome, pentalogy of Cantrell, pectus deformities, bowel malrotation, and genitourinary malformations, but this is variable, ranging from $34 \%$ to $50 \%$ (43). In a large series it was reported that the incidence of $\mathrm{MH}$ associated with Down's syndrome was approximately $20 \%(47,48)$.

Radiographic studies of the chest revealed a density, either solid or containing air, adjacent to the right or left side of the heart. Thoracic CT was the most helpful imaging modality in leading to the diagnosis. Ultrasonography and MRI may sometimes be valuable. Contrast studies of the large intestine and often of the upper gastrointestinal tract may be indicated in the evaluation of some patients (49).

The treatment of asymptomatic $\mathrm{MH}$ is still controversial. There is however, a general consensus that in symptomatic patients, $\mathrm{MH}$ should be treated surgically. The surgical repair can be performed either convention- 
ally by open abdominal or thoracic approaches, or more recently, by minimally invasive surgery $(48,50)$. Hernia sacs is found and removed easily with the approach through the thorax. In addition, this approach has an advantage in case of adhesion between the pericardia and lungs. On the other hand, disadvantages of this approach are that it is difficult to repair bilateral hernias and to diagnose the intestinal obstruction. Herniated organs can be returned to their original places easily with an approach through the abdomen. Particularly, this approach should be used in case of bilateral and central hernias, and combined abnormalities in the abdomen (50).

The recent advances in minimally invasive surgery have made laparoscopic repair of $\mathrm{MH}$ safe and effective in children. Based on some reports, it was concluded that $\mathrm{MH}$ could be successfully managed by laparoscopy $(51,52)$. A variety of techniques to repair $\mathrm{MH}$ laparoscopically have been described in the literature using either primary closure with a continuous suture, interrupted suture, or using a mesh (53). A controversial point is whether to excise or leave the hernia sac. Although some surgeons remove the sacs to identify the fascial edge of the defect (51), some investigators do not favour the procedure due to the risk of perforation of the pericardium and pleura (54). It was reported that leaving the hernia sac plicated in place has no adverse effects $(44,45,55)$. Robotassisted laparoscopic $\mathrm{MH}$ repair was also reported to be safe and feasible in children but the set-up time prolongs the procedure and the overall operative time is longer than the laparoscopic-assisted repair (56).

\section{INTRAPERICARDIAL DIAPHRAGMATIC HERNIA}

Intrapericardial diaphragmatic hernia is a very rare type of diaphragmatic hernia in which there is herniation of abdominal contents into the pericardium. This condition has also been referred to as peritoneopericardial diaphragmatic hernia. It is mostly congenital in children, and traumatic in adults. In the English literature, there are only 15 similar cases reported previously (57). It was suggested that this defect is secondary to failure of fusion of the pars sternalis portion of the septum transversum during the development of the diaphragm (58).

The presentations of this hernia are diverse. Antenatally, it can present as massive pericardial effusion or pericardial mass. Most affected neonates are symptomatic in the immediate postnatal period, with severe respiratory distress and cyanosis secondary to massive pleural effusion or pulmonary hypoplasia $(59,60)$.
Repair may be performed through the abdomen or chest. The abdominal approach is preferred and could be performed using minimally invasive techniques. The defect can be repaired by simple primary closure. When the defect is too large to be closed primarily, a musculofascial flap is advised. Use of prosthetic mesh is not reported in intrapericardial diaphragmatic hernia but can be tried when conventional measures fail (57).

\section{REFERENCES}

1. Grisaru-Granosvky S, Rabinowitz R, loscovich A, et al. Congenital diaphragmatic hernia: review of the literature in reflection of unresolved dilemmas. Acta Pediatrica 2009;98:1874-81. [CrossRef]

2. Golombek SG. The history of congenital diaphragmatic hernia from 1850s to the present. J Perinatol 2002;22:2426. [CrossRef]

3. Irish MS, Holm BA, Glick PL. Congenital diaphragmatic hernia: a historical review. Clin Perinatol 1996;23:625-53.

4. Puri $\mathrm{P}$, Wester $\mathrm{T}$. Historical aspects of congenital diaphragmtic hernia. Pediatr Surg Int 1997;12:95-100. [CrossRef]

5. Iritani I. Experimental study on embryogenesis of congenital diaphragmatic hernia. Anat Embryol 1984;169:133-9. [CrossRef]

6. Allan DW, Greer JJ. Pathogenesis of nitrofen-induced congenital diaphragmatic hernia in fetal rats. J Appl Physiol 1997;83:338-47.

7. Major D, Cadenas M, Fournier L, et al. Retinol status of newborn infants with congenital diaphragmatic hernia. Pediatr Surg Int 1998;13:547-9. [CrossRef]

8. Pober BR. Genetic aspects of human congenital diaphragmatic hernia. Clin Genet 2008;74:1-15. [CrossRef]

9. Waag KL, Loff S, Zahn K, et al. Congenital diaphragmatic hernia: a modern day approch. Semin Pediatr Surg 2008;17:244-54. [CrossRef]

10. Keijzer R, Liu J, Deimling J, et al. Dual-hit hypoplasia in the nitrofen model of congenital diaphragmatic hernia. Am J Pathology 2000;156:1299-306. [CrossRef]

11. Corbett HJ, Losty PD. Congenital diaphragmatic hernia. In Parikh DH, Crabbe DCG, Auldist AW, Rothenberg SS (eds): Pediatric thoracic surgery. Springer-Verlag London 2009, pp. 483-99. [CrossRef]

12. Deprest JA, Gratacos E, Nicolaides K, et al. Changing perspectives on the perinatal management of isolated congenital diaphragmatic hernia in Europe. Clin Perinatol 2009;36:329-47. [CrossRef]

13. Kline-Fath BM. Congenital diaphragmatic hernia. Pediatr Radiol 2012;42 Suppl 1:S74-90. [CrossRef]

14. Stoll C, Alembik Y, Dott B, Roth MP. Associated malformations in cases with congenital diaphragmatic hernia. Genet Couns 2008;19:331-9.

15. Puri P, Gorman F. Lethal nonpulmonary anomalies associated with congenital diaphragmatic hernia: implications for early intrauterine surgery. J Pediatr Surg 1984;19:2932. [CrossRef]

16. Kantarcl S, Ackerman KG, Russell MK, et al. Characterization of the chromosome 1q41q42.12 region, and the Candidate gene DISP1, in patients with $\mathrm{CDH}$. Am J Med Genet 2010;152A:2493-504. [CrossRef] 
17. Graziano JN. Cardiac anomalies in patients with congenital diaphragmatic hernia and their prognosis: a report from the Congenital Diaphragmatic Hernia Study Group. J Pediatr Surg 2005;40:1045-50. [CrossRef]

18. Garne E, Haeusler M, Barisic I, et al. Congenital diaphragmatic hernia: evaluation of prenatal diagnosis in 20 European regions. Ultrasound Obstet Gynecol 2002;19:329-33. [CrossRef]

19. Gallot D, Coste K, Francannet C, et al. Antenatal detection and impact on outcome of congenital diaphragmatic hernia: a 12-year experience in Auvergne, France. Eur J Obstet Gynecol Reprod Biol 2006;125:202-5. [CrossRef]

20. Claus F, Sandaite I, Dekoninck P, et al. Prenatal anatomical imaging in fetuses with congenital diaphragmatic hernia. Fetal Diagn Therapy 2011;29:88-100. [CrossRef]

21. Coackley FV, Glenn OA, Qayyum A, et al. Fetal MRI: a developing technique fort he developing patient. AJR Am J Roentgenol 2004;182:243-52.

22. Muzzafar S, Swischuk LE, Jadhav SP. Radiographic findings in late-presenting congenital diaphragmatic hernia: helpful imaging findings. Pediatr Radiol 2012;42:337-42. [CrossRef]

23. Deprest J, Jani J, Cannie M, et al. Prenatal intervention for isolated congenital diaphragmatic hernia. Curr Opin Obstet Gynecol 2006;18:355-67. [CrossRef]

24. Cannie M, Jani JC, De Keyzer F, et al. Fetal body volume: use at MR imaging to quantify relative lung volume in fetuses suspected of having pulmonary hypoplasia. Radiology 2006;241:847-53. [CrossRef]

25. Takahashi S, Oishi $\mathrm{Y}$, Ito N, et al. Evaluating mortality and disease severity in congenital diaphragmatic hernia using the McGoon and pulmonary artery indices. J Ped Surg 2009;44:2101-6. [CrossRef]

26. Grethel EJ, Nobuhara KK. Fetal surgery for congenital diaphragmatic hernia. J Paediatr Child Health 2006;42:7985. [CrossRef]

27. Harrison MR, Keller RL, Hawgood SB, et al. A randomized trial of fetal endoscopic tracheal occlusion for severe fetal congenital diaphragmatic hernia. $\mathrm{N}$ Engl J Med 2003;349:1916-24. [CrossRef]

28. Deprest J, De Coppi P. Antenatal management of isolated congenital diaphragmatic hernia today and tomorrow: ongoing collaborative research and development. J Ped Surg 2012;47:282-90. [CrossRef]

29. DeKoninck P, Gratacos E, Van Mieghem T, et al. Results of fetal endoscopic tracheal occlusion for congenital diaphragmatic hernia and the set up of the randomized controlled TOTAL trial. Early Hum Dev 2011;87:619-24. [CrossRef]

30. Ladd WE, Gross RE. Congenital diaphragmatic hernia. N Enj J Med 1940;223:917-25. [CrossRef]

31. Breaux Jr CW, Rouse TM, Cain WS, Georgeson KE. Improvement in survival of patients with congenital diaphragmatic hernia utilizing a strategy of delayed repair after medical and/or extracorporeal membrane oxygenation stabilization. J Pediatr Surg 1991;26:333-6. [CrossRef]

32. Kholdebarin R, Iwasiow BM, Keijzer R. Pulmonary development considerations in the surgical management of congenital diaphragmatic hernia. Early Hum Dev 2011;87:755-8. [CrossRef]

33. Reiss I, Schaible T, van den Hout L, et al. Standardized postnatal management of infants with congenital diaph- ragmatic hernia in Europe: the $\mathrm{CDH}$ EURO Consortium consensus. Neonatology 2010;98:354-64. [CrossRef]

34. Barnhart DC, Jacques E, Scaife ER, et al. Split abdominal wall muscle flap repair vs patch repair of large congenital diaphragmatic hernias. J Pediatr Surg 2012;47:81-6. [CrossRef]

35. Valfre L, Braguglia A, Confrotti A, et al. Long term followup in high-risk congenital diaphragmatic hernia survivors: patching the diaphragm affects the outcome. J Pediatr Surg 2011;46:52-6. [CrossRef]

36. Moss RL, Chen CM, Harisson MR. Prosthetic patch durability in congenital diaphragmatic hernia: a longterm follow-up study. J Pediatr Surg 2001;36:152-4. [CrossRef]

37. Masumoto K, Nagata K, Souzaki R, et al. Effectiveness of diaphragmatic repair using an abdominal muscle flap in patients with recurrent congenital diaphragmatic hernia. J Pediatr Surg 2007;42:2007-11. [CrossRef]

38. Sugiyama A, Fukumoto K, Fukuzawa $\mathrm{H}$, et al. Free fascia lata repair for a second recurrent congenital diaphragmatic hernia. J Pediatr Surg 2011;46:1838-41. [CrossRef]

39. Tsao K, Lally PA, Lally KP. Minimally invasive repair of congenital diaphragmatic hernia. J Pediatr Surg 2011;46:1158-64. [CrossRef]

40. Di Pace MR, Caruso AM, Farina F, et al. Evaluation of esophageal motility and reflux in children treated for congenital diaphragmatic hernia with use of combined multichannel intraluminal impedance and $\mathrm{pH}$ monitoring. J Pediatr Surg 2011;46:1881-6. [CrossRef]

41. Danzer E, Hedrick HL. Neurodevelopmental and neurofunctional outcomes in children with congenital diaphragmatic hernia. Early Hum Dev 2011;87:625-32. [CrossRef]

42. Frisk V, Jakobson LS, Unger S, et al. Long-term neurodevelopmental outcomes of congenital diaphragmatic hernia survivors not treated with extracorporeal membrane oxygenation. J Pediatr Surg 2011;46:1309-18. [CrossRef]

43. Pokorney WJ, McGill CW, Herberg FJ. Morgagni hernia during infancy: presentation and associated anomalies. J Pediatr Surg 1984;19:394-7. [CrossRef]

44. Mallick MS, Alqahtani A. Laparascopic-assisted repair of Morgagni hernia in children. J Pediatr Surg 2009;44:16214. [CrossRef]

45. Akbıyık F, Tiryaki TH, Şenel E, et al. Is hernial sac removal necessary? Retrospective evaluation of eight patients with Morgagni hernia in 5 years. Pediatr Surg Int 2006;22:8257. [CrossRef]

46. Slavotinec AM. The genetics of congenital diaphragmatic hernia. Semin Perinatol 2005;29:77-85. [CrossRef]

47. Çiğdem MK, Önen A, Okur H, Otçu S. Associated malformations in Morgagni hernia. Pediatr Surg Int 2007;23:1101-3. [CrossRef]

48. Al-Salem AH, Nawaz A, Matta H, Jacobs A. Herniation through the foramen of Morgagni: early diagnosis and treatment. Pediatr Surg Int 2002;18:93-7. [CrossRef]

49. Zaleska-Dorobisz U, Bagłaj M, Sokołowska B, et al. Late presenting diaphragmatic hernia: clinical and diagnostic aspects. Med Sci Monit 2007;13(Suppl 1):137-46.

50. Kılıç D, Nadir A, Döner E, et al. Transthoracic approach in surgical management of Morgagni hernia. Eur $\mathrm{J}$ Cardiothorac Surg 2001;20:1016-9. [CrossRef]

51. Arca MJ, Barnhart DC, Lelli JL, et al. Early experience with minimally invasive repair of congenital diaphragma- 
tic hernias: results and lessons learned. J Pediatr Surg 2003;38:1563-8. [CrossRef]

52. Shah SR, Wishnew J, Barsness K, et al. Minimally invasive congenital diaphragmatic hernia repair: a 7-year review of one institution's experience. Surg Endosc 2009;23:126571. [CrossRef]

53. Dutta S, Albanese CT. Use of a prosthetic patch for laparoscopic repair of Morgagni diaphragmatic hernia in children. J Laparoendosc Adv Surg Tech A 2007;17:3914. [CrossRef]

54. De Vogelaere K. Laparoscopic repair of Morgagni diaphragmatic hernia. Surg Laparosc Endosc Percutan Tech 2003;13:401-3. [CrossRef]

55. Alqahtani A, Al-Salem AH. Laparascopic-assisted versus open repair of Morgagni hernia in infants and children. Surg Laparosc Endosc Percutan Tech 2011;21:46-9. [CrossRef]

56. Anderberg M, Kockum CC, Arnbjornsson E. Morgagni hernia repair in a small child using da Vinci robotic instruments-a case report. Eur J Pediatr Surg 2009;19:1102. [CrossRef]

57. Jain V, Choudhury SR, Chadha R, Puri A. Intrapericardial diaphragmatic hernia: a rare type of congenital diaphragmatic hernia. J Pediatr Surg 2011;46:E29-E31. [CrossRef]

58. Milne LW, Morosin AM, Campbell JR, Harrison MW. Pars sternalis diaphragmatic hernia with omphalocele: a report of two cases. J Pediatr Surg 1990;25:726-730. [CrossRef]

59. Davies MR, Oksenberg T, Da Fonseca JM. Massive foetal pericardiomegaly causing pulmonary hypoplasia, associated with intra-pericardial herniation of the liver. Eur $\mathrm{J}$ Pediatr Surg 1993;3:343-7. [CrossRef]

60. Hara K, Kikuchi A, Takagi K, et al. Massive pericardial effusion in an early gestational fetus having intrapericardial diaphragmatic hernia. J Obstet Gynaecol Res 2007;33:561-5. [CrossRef] 